\title{
MOTIVATING STUDENTS AT A DISTANCE: THE CASE OF AN INTERNATIONAL AUDIENCE
}

\author{
Lya Visser \\ Tjeerd Plomp \\ Ray J. Amirault \\ Wilmad Kuiper
}

Distance education is rapidly becoming an increasingly important - and even preferred method of instructional delivery for many educational contexts. In spite of the many student benefits surrounding distance learning programs, however, a great number of distance learning courses suffer from extremely low student completion rates when compared to their traditional classroom-based counterparts. Although it may be tempting to point to instructional content and methods as the source of low distance learning completion rates, it can be shown that it is often motivational problems, and not the instruction itself, which lay at the root of these statistics. This article describes the motivational issues encountered by a representative group of international distance education students, as well as a specific, low-cost motivational intervention that assisted the instructors of these students to improve completion rates by providing effective and efficient motivational student support.

This article is based on research focused on specific methods to increase course completion rates in a distance education program. Prior research has indicated that lack of motivation is an important cause of dropouts when students choose to study at a distance (Wolcott \& Burnham, 1991; Zvacek, 1991). The results of such research speak to the need that instructional designers and instructors understand motivational principles and be able to apply validated motivation-enhancing techniques to overcome the frequent motivational issues surrounding the distance learning community.

The challenge in motivating distance learners is complicated by the fact that it is generally easier to detect and correct motivational problems in conventional teaching and learning settings than in distance education settings. In the face-to-face context, 
instructors have more frequent contact with learners, a fact which helps instructors identify and address less motivated students. In addition, the traditional learner's face-toface participation in group work as well and oftentimes frequent contact with peers can also directly enhance motivational levels in students. In distance education settings, however, student motivational problems can go unnoticed and undetected for extended periods, and neither do students directly benefit from the personal contact experienced by traditional students. As a result, distance learners may not receive the timely help that would bring about higher levels of motivation when it is truly needed most by these students.

Technological advances have improved distance learning delivery, but have not necessarily addressed student motivation needs. It is indeed true that today's Internetbased communication technologies are rapidly becoming a fact of life in many parts of the world and are increasingly penetrating the learning environment, but in spite of the potential for these technologies to offer interesting, efficient and effective opportunities for learning, it should be recognized that human beings continue to have the same motivational requirements in today's technology-based world that were present in the past (Keller, 1999). This notion appears to be easily forgotten by today's educational research community. For example, in a recent listing (see Table 1) of the papers presented at the World Conferences of the International Council for Distance Education (ICDE) between 1988 and 1995, the number of presentations focusing on motivation issues occupied an extremely small proportion of all presentations made, in spite of the critical importance of the subject to distance learning. It may also be noted that a similar trend in the lack of attention paid to motivation in distance education is present in some of the recently published specialized handbooks in the field of distance education.

Table 1 Overview of papers dealing with motivation presented at four ICDE conferences

Year

1988 1990
Papers presented 102 77
Papers related to motivation

2

2 
The condition of being "motivated" has been described as an autonomous disposition, a state of being which the learner himself controls, and which can be affected by outside influences only to the extent permitted by the learner (J. Visser, 1989). This being the case, it is almost always a challenge to develop motivational interventions which will appeal to the learner in such a way as to be affected by such interventions. The challenges were even greater in the case of this particular study, which not only addressed the direct motivational needs of learners, but did so in the context of students living and studying in developing countries, where communication technology can be limited, and access to fax and/or email may not be available.

In reaching out to these students, for example, it was necessary to develop a communication instrument that made it possible to establish contact between the student and the instructor (and vice versa) that did not depend on sophisticated technology. It is known that instruction and communication in distance education is only possible on the basis of instrumentally rational and strategic action (Bates, 2000; Moore \& Kearsley, 1996). The instrument of communication itself, however, does not necessarily have to be a sophisticated one. In the case of this study, for example, an institutional communication system largely based on the use of traditional postal services was used to stay in touch with the students during their coursework. Using written messages that aimed at helping students to become or stay motivated was used to promote interaction and to help learners adjust their unique motivational levels.

The study sought to answer the following research question:

To what extent, if any, will a motivational component in the form of motivational communications result in a significant increase in the percentage of students who successfully finish the course? 
In attempting to answer this research question, the study not only examined the design and the content of student-teacher communication, but also examined the effectiveness and the process of administering such communication. A research approach that met the need for gradual and evolutionary development of a product, called the motivational message, was adopted. (The idea of using motivational messages originated in a face-toface instructional context [J. Visser, 1989], and had to be reinvented for application in a distance education environment.) The motivational message should be seen as a product under development, the content of which is influenced by factors like the motivational disposition of the learners, student's academic records, social and cultural circumstances, and language. Ongoing formative evaluation was necessary to improve the motivational messages while they were being developed in order to make them valid, practical and effective.

Developmental research is carried out to optimize and gain a sound basis for future activities and has a twofold aim:

- Development of a prototypical product (i.e., the motivational message).

- Generating methodological directions for the development of such a product (Van den Akker \& Plomp, 1993).

These aims agree with the description of developmental research by Richey and Nelson (1996). They distinguish two types of developmental research:

- Research studies in which the product development process is described, analyzed, and the final product evaluated (Type 1 research).

- Research studies directed towards a general analysis of the design, development or evaluation as a whole, or towards any particular component of the research (Type 2 research).

The study discussed in this paper qualifies as a Type 1 study. As such, the study analyzes and describes the development process of a product (a motivational message) in a given situation (a distance education program) and evaluates the product (the prototype) in a pilot study through formative evaluation and, in the context of a multiple case study (Yin, 1994), through summative evaluation. The front-end analysis was based on the 
assumption that the same motivational messages which had successfully been used in traditional education to adjust the motivational levels of learners (J. Visser, 1989) could also be effective in student support in a distance education context.

\section{The Motivational Intervention}

A theoretical basis for the development of motivational messages can be established by examining what prior research has said about motivational issues. First, as stated previously, motivation plays an important role in the successful completion of an educational learning task. Briggs (1980), for example, is of the opinion that our theories or models of design do not sufficiently take motivation into account, even though we may acknowledge that motivation effects are stronger than treatment effects. Bohlin (1987) is convinced that motivation is the backbone of effective instruction, while Zvacek (1991) writes that the role of motivation in the distance education process cannot be overstated. These and other researchers have spoken to the critical importance of motivation in the educational setting.

Moving beyond the established importance of motivation in education, researchers have sought to more closely specify and distinguish an exact definition of what it means to be "motivated." Deci, for example, distinguishes between motivation and compliance (Deci, 1996). According to Deci, motivated individuals are fully willing to do what they are doing, approaching tasks with interest and commitment. Compliance, on the other hand, refers to a state in which an individual performs a task because he or she has been told to do it (Deci, 1996). Motivation thus refers to the wish, the desire to pursue a goal, the desire to realize a task. An important question therefore is to ask how we as educators can create the conditions to motivate learners and not simply make them compliant to some educational system.

Motivation can be viewed as both the magnitude and the direction of the learner's behavior. As such, motivation refers to choices people make as to how they engage and what effort they will exert (Keller, 1983; Keller \& Litchfield, 2002). Further, motivation 
is often divided into two major types: extrinsic motivation and intrinsic motivation. Motivation is said to be extrinsic in nature when the force of the motivation comes from outside the learner. Generally this means that there is some external goal that is more important to the learner than the process of reaching that goal, thus making the goal the reason for the behavior. (Examples of extrinsic motivation include a pay raise, a career move or the praise of superiors and relatives.) Motivation is said to intrinsic in nature when the force of the motivation comes from the wish to do something for the pleasure of engaging in the activity. In this case, the activity itself is rewarding (Stipek, 1998), and the learner is wholly involved in the activity itself without necessarily a great deal of concern for reaching some external goal (for example, getting paid for a completed task). The available options for improving the retention rate in distance learning courses are dependent on whether the interventions are to be applied to a new or existing course. When designing new distance education courses, motivational strategies should be built into the design of instructional materials (as well as into the procedures that guide students through their course work). In existing courses, a choice must be made to either redesign the instructional materials by including improved quality and quantity of motivational strategies, or to extend existing student support systems with motivational strategies. The developmental study presently under discussion focuses on an intervention applied in an existing distance education environment, and concentrated on the student support system (not the instruction), as it was deemed to be a less costly and more immediate solution to the motivational issues found to be present in the instructional setting.

The discipline of Educational Psychology has seen the development of a number of motivational theories and models over the past few decades. Deprivation and reinforcement was the basis of behavioral theories, intrinsic motivation and attribution that formed the basis of the cognitivist view (Graham \& Weiner, 1996; Stipek, 1996). Wlodkowsky (1985) developed the Time Continuum Model of Motivation. This is a prescriptive model that stipulates which motivational strategies to use at specific intervals. The humanistic perspective focuses on innate, qualitative differences in psychological processes. Rogers (1969) believed that the central motivating force for 
people is the actual process of growth and achieving wholeness, while Maslow's (1954) theory of need gratification emphasized motivation as a condition to develop one's full potential.

These theories and models do not, however, offer systematic guidelines for instructional design. According to Keller (1999), three assumptions underlie systematic motivational design: that people's motivation can be influenced by external events; that motivation, in relation to performance, is a means, and not an end; and that systematic design and implementation can predictably and measurably influence motivation (Keller, 1999). Keller's ARCS model seeks to address these motivational issues for the instructional context.

The ARCS model (Keller, 1983) is useful for instructional design as it helps to understand the construct of motivation in four distinct categories (Attention, Relevance, Confidence, Satisfaction). The model provides a systematic motivational design process as well as the opportunity to implement a number of motivational strategies and tactics. The ARCS model has certain similarities with Wlodkowsky's Time Continuum Model of Motivation (1985), but differs in that the ARCS model has strategy selection from a set of categories and subcategories based on a synthesis of concepts and theories in human motivation, and is thus a flexible model: Wlodkowsky's model, on the other hand, is a prescriptive solution. Because the solutions for motivational problems are usually multidimensional in that they include elements related to all major influences on motivation, the more non-prescriptive approach of the ARCS model has been proven to be practical, widely applicable, and has additionally withstood the test of cross-cultural applications (Keller, 1999). The ARCS model has also has successfully been used in research on motivational interventions in a face-to-face context (J. Visser, 1989).

The four components of the ARCS model (Attention, Relevance, Confidence, and Satisfaction) used for motivational analysis represent the most important dimensions of human motivation: 
Attention. Attention is a necessary condition for the learner to focus is on the learning task. Attention is likely to be more difficult in distance education than in conventional education due to the separation of time and space present in such contexts. Strategies used to arouse and maintain attention include challenging, unexpected or even provocative communication, frequent communication, rapid feedback and genuine (i.e., not feigned) interest in the learner.

Relevance. The ARCS model states that learners are more likely to be motivated if they can see the specific relevance of a course or instructional lesson. Learners should be helped to see how the courses they are following can contribute to solving their (professional) problems and how courses can enrich their performance and their life in general. As most distance education students struggle with conflicting interests (much like their colleagues in conventional education), they should be helped to define priorities. Extra help could be offered by making available examples of assignments.

Confidence. Confidence can be increased by establishing a positive expectancy of success on the part of the learner. It is important to help students build confidence by stating the expected learning outcomes in a clear manner when initiating a learning task and by providing frequent opportunities for learners to see themselves successfully approaching the desired outcome. Chunking of the instruction into manageable portions can help students feel that they are in control, thereby improving confidence. Lack of confidence may be an especially prevalent problem in distance education since the distance learning context is new for many learners. (Students are generally more familiar with traditional education, in which they have usually been successful, and they feel at ease in a face-toface context: they are often not familiar with distance education, may have limited experience in working on their own, and would frequently prefer to be taught by a teacher.) In addition, fear of failure may also be high for distance learners. Consequently, confidence enhancing strategies are important to counter the feelings of inadequacy which may arise from this new learning context. 
Satisfaction. To sustain the student motivation, satisfaction must be present. Satisfaction refers to positive feelings about what has been accomplished in the learning context. Distance learners may need frequent evidence of success as they progress through the learning process, as such evidence supports student's intrinsic feelings of satisfaction. Frequent, timely and encouraging feedback is an important satisfaction strategy. Students should be encouraged that if they work hard, they can and will be successful. A clear consistency between objectives, content and assignments is also a helpful motivational strategy to build satisfaction in students.

The original ARCS model of motivation contains an eight-step design process for the development of motivational strategies (Keller, 1987). For the development of the specific motivational communications used in the present study, the standard design process was simplified by combining steps, resulting in a four-step design process. Step 1 gives information about the status quo and provides the basis for analysis of motivational needs in Step 2. Step 3 prepares objectives, based on the preceding two steps, for performance improvement, while the final step, Step 4, looks at acceptable solutions for the situation under examination. A more detailed description of the steps and their applications to the distance education mode follows.

\section{Step 1}

\section{Environmental and audience information}

Data collection on the program, course materials, implementation processes and instructional processes is performed. Detailed information on the international students, student social and cultural background, reasons for taking the course, and student expectations and expected motivational problems is collected.

\section{Step 2}

\section{Environmental and audience analysis}

Based on information obtained in Step 1, an audience analysis is conducted. The audience analysis consists of a socio/geographic motivational profile. Analysis of the environment, including problems and deficiencies of program/course, of the providing institution and of student's environment are also conducted. 
Step 3

Objectives, measures and preliminary design

Information collected in Step 2 is used to define the motivational objectives and the content of the communications/messages. Any motivational tactics which are created are need-based. Initial concept for design of motivational messages is developed.

Step 4

Final design, development and testing

Incorporation of enhancing and sustaining tactics in the motivational communications. Integration into the existing student support system. Formative evaluation of messages.

The above four-step model was used in the research discussed in this article for the design and development of a first (prototype) motivational message. Based on student feedback, the prototype message was improved and initiated a process of formative evaluation in which different prototypes were improved so that formative evaluation, a crucial component of developmental research, could be carried out. Consistent with the procedures common to developmental research, a pilot study preceded the main study.

\section{METHOD}

As part of the study, a pilot phase was designed to obtain information on the characteristics of effective motivational messages, following the principles of the ARCS model of motivational analysis. The objective of the pilot study was to develop a motivational message that would be valid, practical and effective, and which would subsequently be used in the multiple case portion of the study. The motivational message should therefore be viewed as the result of a process of continuous improvement which originated with a single prototype message.

\section{Context and Participants Pilot Study}

The pilot study took place in one of the largest academic institutions in the United Kingdom. The university offers undergraduate and graduate programs in a variety of 
fields via both conventional and distance education. A well-known affiliated college with a rich experience in developing and delivering distance education internationally is the organization responsible for the delivery and administration of the Diploma and MA programs in Distance Education.

The research took place within a Master's program in Distance Education administered by this college. The program consists of four foundation courses, three elective courses at the advanced level and a thesis. Each course lasts nine months. Students in attendance come from all parts of the world, with the majority from developing countries (and where the use of Internet and fax technology is limited). Most students take two courses at a time. All courses are self-contained and use audio-tapes in addition to printed material.

At the time the research was carried out, interaction between students and instructors took place via conventional postal services. This meant that it took instructors an average of ten days to reach students and vice versa. The role of the instructor - specified in the service contract - was limited to sending a welcome letter, grading and giving feedback on a minimum of two and a maximum of four assignments per course. There was no other institutionalized contact between student and instructor. The researcher worked as an instructor in the program. From a research perspective, her role was that of a participant observer who could look at the evolving communication process between students and instructors from the inside of the system.

Nineteen international students participated in the pilot study: eleven women and eight men, from thirteen different (mostly developing) countries. The average student age was forty-one years. Two students dropped out during the first two weeks of the course, one because she was transferred to another position and the program was no longer relevant for her performance in the new context, the other one because she could not cope with the combination of work and study.

Instruments 
The following instruments were used to determine the effect of motivational communications (messages):

- The student records provided by the college

- Interviews with the student counselor

- Interviews with the Director of Studies

- End of course questionnaires

- End of the course interview with the student counselor

\section{Motivational Intervention}

Based on the available data a student profile was made that focussed on the motivational needs of the learners. The initial, limited, audience analysis had shown that many students were uncertain about their ability to finish the course successfully as they feared they might have time management problems and lack the required academic background and/or did not have the necessary study skills. Lack of confidence was thus identified as an important problem. During the pilot study, as more information from the students became available about their motivational needs and their problems, the initial motivational profile was regularly modified, but lack of confidence continued to be the main problem.

Motivational communications were designed based on the four steps for the development of motivational strategies already presented. Table 2 provides both the aim and the related components of the ARCS model for each of the prescribed motivational messages.

The first motivational communication was in the form of a letter. The aim of this first message was to establish a relationship of trust between the instructor and the student and to emphasize that if students worked hard and submitted their assignments in time their chances for success would be optimal. The second motivational communication, sent a month later, was also in the form of a letter. This message suggested a study calendar and indicated that instructors would assist students in adhering to the calendar. The positive 
reactions to these first two messages influenced the researcher's decision to develop another format for a new motivational message: a birthday card. The birth card message had an appealing, one-line phrase on its' outer face and a reinforcing text on the inside of the card.

The third message also used motivational strategies targeted at building confidence. The fourth message had a short text on the outside of the card, and also featured an illustration that reinforced the text. The inside of the card contained a more extensive text. The students often received a message with an extra handwritten line added such as, "I'm proud of your work," or "I'm sure you can do it".

The remaining messages also were used to target specific motivational issues that can arise during the course of the class. Message 5 was sent to the eight students who had not submitted their assignments in time. Message 6 reminded students of the upcoming exam and urged them to send in assignments. Message 7 wished the learners good luck and additionally provided some exam hints. The last message, Message 8, congratulated those students who had completed the exam, and encouraged others to do so as soon as possible. The cover of Message 8 used a collage of observations and remarks from students collected over the year. The specific targets of each of these eight messages as they apply to ARCS are listed in Table 2. This table also gives evidence as to how the prototype message evolved over time.

Table 2 Overview of the motivational messages sent out during the pilot study

\begin{tabular}{|c|c|c|c|c|}
\hline Message & Month & Format & Aims & $\begin{array}{l}\text { ARCS } \\
\text { component }\end{array}$ \\
\hline 1 & March & Letter & $\begin{array}{l}\text { Welcome; study advise-students can be } \\
\text { successful if they work hard. }\end{array}$ & A C \\
\hline 2 & April & Letter & $\begin{array}{l}\text { Study plan; submit assignment in time, } \\
\text { information on colleagues. }\end{array}$ & A C S \\
\hline 3 & May & $\begin{array}{l}\text { Card, text } \\
\text { only }\end{array}$ & $\begin{array}{l}\text { Encouragement to discuss course/learning } \\
\text { problems; assurance that students can be } \\
\text { successful. }\end{array}$ & A C \\
\hline 4 & June & Card with & Reminding students of deadline of assignment; & A C S \\
\hline
\end{tabular}




\begin{tabular}{|c|c|c|c|c|c|}
\hline & & $\begin{array}{l}\text { graphics and } \\
\text { text }\end{array}$ & $\begin{array}{l}\text { promising speedy feedback; emphasizing } \\
\text { eventual success. }\end{array}$ & & \\
\hline $5^{1}$ & July & $\begin{array}{l}\text { Card with } \\
\text { graphics and } \\
\text { text }\end{array}$ & $\begin{array}{l}\text { Reminder that assignment is due; emphasis on } \\
\text { students' own role in being successful. }\end{array}$ & A & $S$ \\
\hline 6 & Aug & $\begin{array}{l}\text { Card with } \\
\text { graphics and } \\
\text { text }\end{array}$ & $\begin{array}{l}\text { Reminder to students who have not sent in } \\
\text { assignment; reference to exam; assurance that } \\
\text { students will do well if they keep going. }\end{array}$ & A & C S \\
\hline 7 & $\begin{array}{l}\text { Late } \\
\text { Sept }\end{array}$ & $\begin{array}{l}\text { Card with } \\
\text { graphics and } \\
\text { text }\end{array}$ & $\begin{array}{l}\text { Reassuring students for their exams; exam } \\
\text { advice; congratulating students on having come } \\
\text { so far. }\end{array}$ & & C S \\
\hline 8 & $\begin{array}{l}\text { Early } \\
\text { Nov }\end{array}$ & $\begin{array}{l}\text { Card with } \\
\text { graphics and } \\
\text { text }\end{array}$ & $\begin{array}{l}\text { Congratulations to those who sat the exam; } \\
\text { encouragement to those who did not do so to } \\
\text { take the next chance. }\end{array}$ & $\mathrm{C}$ & S \\
\hline
\end{tabular}

Student reactions arrived four to six weeks after the message had been sent out. Table 3 gives a description of the most significant remarks received from the students. It should be noted that these reactions were all in the form of letters sent to the instructor by ordinary mail. The process of a student getting such a message to the instructor required special effort, particularly for students living in difficult circumstances in developing countries, and speaks to the strength of the motivation possessed by these students.

Table 3 Reactions of students to the messages

\section{Message $\quad$ Remarks and observations made by students}

Five reactions: students felt encouraged; personally touched; cared for.

2

Five reactions: two students also reacted to the first message, appreciated messages; thanked for concern; two thanked for advice.

3

Three reactions: "thanks for encouragement"; "thanks for the encouragement this note gave me"; "I will stay in touch".

4

Two reactions: "thanks for the reminder, I was both amused and pleased that someone cared to that extent"; "I now realized how important personal contact is".

\footnotetext{
${ }^{1}$ Only for those students falling behind
} 
Two reactions: "Thanks for the encouraging message"; "Thanks for the interesting (sic) in my person". ideas and encouragement".

$\mathrm{N}=10$

\section{Results of the pilot study}

Student reactions to the motivational messages give clear evidence that these students appreciated receiving the messages as they took the course. For example, two of the students referred specifically to the drawings. One message was colored in by the student's daughter (who thought that the black and white photocopy could be improved upon) and returned to the instructor. Another message (Message 7) showed the heads of a number of different people: white, black, old, young, female, male, and had as catching phrase: 'You're one of them'. One of the students wrote the researcher, saying his little daughter had said that this message's picture could not be true, since no one depicted in the drawing had both a mustache and a beard as the student did. Reactions such as these showed that the messages assumed a place in the students' daily lives, particularly in the family environment.

In addition, students sent many unsolicited reactions that did not specifically refer to one particular message, but more to their own insecurities or circumstances. The following examples may suffice: "I wonder whether I will ever make it"; "tempus fugit"; "Let's hope my TMA [assignment] looks still good after you have marked it". There were also notes of optimism and confidence: "As for the grade, I just hope the next one will be better"; "The distance form of education has given me a chance"; "Without the personal approach through the messages I might have given up"; "The notes show warmth and care". 
At the end of the course, and before the grades were out, a questionnaire was sent to the 17 remaining students (two had dropped out in the first weeks of the course). The five questions contained in the questionnaire probed student feelings about the motivational messages. These responses are tabulated and listed in Table 4.

Table 4 Answers of students to five core questions in the final questionnaire

\begin{tabular}{|c|c|c|c|c|c|c|}
\hline Question & Description & $\begin{array}{l}\text { Agree } \\
\text { strongly }\end{array}$ & $\begin{array}{l}\text { Agree } \\
\text { partly }\end{array}$ & $\begin{array}{l}\text { Agree nor } \\
\text { disagree }\end{array}$ & $\begin{array}{l}\text { Disagree } \\
\text { partly }\end{array}$ & $\begin{array}{l}\text { Disagree } \\
\text { strongly }\end{array}$ \\
\hline 1 & $\begin{array}{l}\text { The first letter } \\
\text { encouraged me to make } \\
\text { a good start }\end{array}$ & 5 & 5 & & - & - \\
\hline 2 & $\begin{array}{l}\text { I liked receiving letters } \\
\text { better than little notes }{ }^{2}\end{array}$ & 3 & 1 & 3 & 2 & 1 \\
\hline 3 & $\begin{array}{l}\text { The notes encouraged } \\
\text { me to go on with the } \\
\text { course }\end{array}$ & 5 & 3 & 1 & - & - \\
\hline 4 & $\begin{array}{l}\text { During the year I was } \\
\text { looking forward to } \\
\text { receiving the notes }\end{array}$ & 3 & 3 & 3 & - & - \\
\hline 5 & $\begin{array}{l}\text { Without the little notes } \\
\text { I would not have } \\
\text { continued my course }\end{array}$ & 1 & 2 & 4 & - & 3 \\
\hline
\end{tabular}

$\mathrm{N}=10$

The researcher also sought to determine which motivational messages students had been most preferred by students. Seven of the 10 students indicated that they preferred the note that showed the learners as a group (Message 7, "You're one of them"). One student indicated that "All notes were very encouraging and stimulating". The messages in the form of a birthday card with text and graphics were viewed favorably, and all messages that emphasized that learners could complete the course successfully, as well as messages that mentioned that all students were working toward the same goal, were also rated favorably. Asked if students could attempt to describe what they felt was the underlying 
purpose of the messages (the term "motivational message" was not used in order to keep responses less affected by the question's wording), encouragement and motivation were both mentioned six times, communication and personal touch were mentioned four times, and a reminder of study commitments were mentioned three times. (Some of the students gave two purposes.)

The study also saw an increase in the completion rate for the course. In the previous year, the course had an enrollment of 19 students, with seven students fully completing the course, or a completion rate of approximately $37 \%$. When the motivational messages were applied in the same course, also with an enrollment of 19 students, 11 students completed the course, increasing the completion rate to $58 \%$, a substantial increase when compared to the previous year.

\section{Discussion results of pilot study}

The pilot study provided evidence that the use of motivational messages favorably influenced the course completion rate, and that students reacted favorably to the motivational message approach. Personalizing the messages with motivational content that was based on the individual needs of students had, however, been a time consuming process. Seven different prototypes were designed and developed, students' motivational needs monitored, and data collected throughout the process were all time consuming aspects of the developmental research approach employed in the pilot study. In addition, the characteristics of the pilot study made it apparent to the researcher that further insight into the best use of motivational messages was necessary. Specifically, the pilot study had been limited in terms of student participants, and had also been carried out by the researcher who was also the instructor in the class involved in the pilot study. The need for a greater number of participants, as well as the concern for the researcher also serving as the instructor, made it necessary to consider some alterations in the manner to which the full study would be carried out.

\footnotetext{
${ }^{2}$ Students used to call the messages 'little notes'
} 
In the main study, these issues were addressed by modifying the research process in ways that resulted in a strengthening of the general findings that motivational message enhance student motivation and result in higher student completion rates. For example, instead of serving in a dual role of instructor and researcher, the researcher employed other instructors who could administer the intervention independently, thus eliminating contamination of the student population via the presence of the researcher in the instructional role. Further, a larger number of students were employed, but this increase in participants also necessitated a streamlining of the message process. It was therefore decided to administer motivational messages by doing a motivational analysis at the beginning of the course (not monitoring the motivational needs during the course, as in the pilot study), and have all students receive the same messages (not individually personalized messages) during the course.

\section{THE MAIN STUDY}

To establish further insights into the effectiveness, efficiency, and cost issues of the messages as defined in the pilot study, the main study was extended to a larger group of students, and the number of courses involved increased to five. A multiple case perspective was chosen to strengthen the validity base of the strategy of using motivational messages to enhance motivation. Two types of motivational messages were used: personalized motivational messages, based on an initial motivational analysis of two groups of course participants and on monitoring students' personal motivation (selfreporting), and collective motivational messages, based on an initial motivational analysis of two other groups of course participants. Collective messages thus were uniform in format and content, while in personalized messages the uniform generic text could be changed and enriched by adding a few words that specifically addressed the individual student receiving the message and his or her motivational needs. In the case of personalized messages, a special message was sometimes designed for the individual student. Each course was considered a separate case in which either the personalized or the collective messages were used (for example, one group of course participants did not receive any messages.) Instructors in the courses would record the time spent on the two 
different approaches. The characteristics of the case study conformed to Yin's (1994) description of a case study as one that deals with operational links to be traced over time, rather than with mere frequencies of incidence.

The environment of the study

The main study took place in the identical environment as the pilot study, utilizing the same university and implementing college. Students in the courses studied came from five different continents and twenty-two countries. Most of the students used English as their second language. All interactions with the students made use of the normal postal services.

\section{The participants}

A total of 81 students within five courses participated in the study. The number of students for each course, as well as the specific motivation activity and instructor in each case, is depicted in Table 5. The average age of the students was 39, and slightly more than half the students were women (56\%). All students were professionally active in education, and most of them in distance education environments. Three of the four instructors had previous experience working in this specific program. Two of the instructors held Ph.D.'s; the other two instructors held Master's degrees. In addition, three of the four instructors had been teaching in developing countries in similar academic situations.

Table 5 Courses involved in the study

\section{Course}

A

B

C

D
Number of students

18

13

14

18
Motivational Activity

None

Collective messages

Personalized messages

Collective messages

\section{Instructor}

Jane $^{3}$

Researcher

Researcher

Rick

\footnotetext{
${ }^{3}$ All names in this article are fictitious
} 
Instruments

The following student-related instruments and data were used:

- Initial questionnaire (administered upon enrollment) to obtain information on reasons for taking the course, areas in which motivational problems were expected, expectations as to student support, and demographic data.

- Final questionnaire (administered after the course was completed, but before grades were sent) to obtain information on which messages students had most preferred, the reasons why, the perceived relevance of the messages, and the perceived reasons for sending such messages.

Telephone interviews with two students identified by the college were also conducted. One student in the telephone interview was a third time repeater, and the other a person unhappy with the program. Both students interviewed by telephone had completed the course.

The following instructor-related instruments and data collection methods were used:

- Course completion records of three preceding years.

- Structured questionnaires asking instructors about their past teaching experience in the courses, administered prior to the beginning of the course.

- Logbooks used to register instruction and grading time and student remarks

- Telephone interviews concerning the perceptions of three instructors as to the effectiveness of the motivational intervention.

- A telephone interview with the director of studies on how he had experienced the intervention. 
- An interview with two college administrative staff in regard to the administrative procedures.

The motivational intervention

The most frequently-referenced area of learner motivational need in both the pilot study and the initial main study questionnaire was confidence. Such a finding was not surprising. Since virtually all learners made a conscious, willing choice to enroll in the course, they most likely would not expect to have great difficulties within the relevance component of the ARCS model. It was, however, possible that the two other ARCS factors, i.e., attention and satisfaction, would become significant issues during the course as initial excitement wore away and the goal of being successful less in the student's mind.

To use the ARCS model most efficiently and effectively in this distance education setting, a simplified motivational design (Suzuki \& Keller, 1996) was adopted for use in the study. Additionally, specific adaptations to this approach were based on the results of the pilot study and the initial student and instructor questionnaires for the multiple case study. The adapted design is presented in Table 6.

Table 6 Adapted design for motivational messages in the multiple case study

\begin{tabular}{|l|l|l|l|l|}
\hline Factors & Attention & Relevance & Confidence & Satisfaction \\
\hline $\begin{array}{l}\text { Pre-course } \\
\text { attitudes of } \\
\text { students related } \\
\text { to distance } \\
\text { learning }\end{array}$ & $\begin{array}{l}\text { Strong: new } \\
\text { course/materials, } \\
\text { diminishing as } \\
\text { novelty wears off }\end{array}$ & $\begin{array}{l}\text { Strong: Decision to take } \\
\text { mostly not imposed; } \\
\text { possible increase when } \\
\text { applying what has been } \\
\text { learned }\end{array}$ & $\begin{array}{l}\text { Low: first time distance } \\
\text { learners anxious: } \\
\text { Higher for experienced } \\
\text { learners }\end{array}$ & $\begin{array}{l}\text { Initially strong: } \\
\text { successful } \\
\text { completion step } \\
\text { towards degree. } \\
\text { May wear off. }\end{array}$ \\
\hline $\begin{array}{l}\text { Midterm } \\
\text { attudes }\end{array}$ & $\begin{array}{l}\text { Moderate: } \\
\text { Curiosity wears } \\
\text { off, print-based } \\
\text { courses with only } \\
\text { audio cassettes can } \\
\text { be boring }\end{array}$ & $\begin{array}{l}\text { Mossibility to show what } \\
\text { has been learned }\end{array}$ & $\begin{array}{l}\text { Poor: limited academic } \\
\text { support and no } \\
\text { motivational support }\end{array}$ & $\begin{array}{l}\text { Moderate: } \\
\text { dissatisfaction may } \\
\text { set in as students are } \\
\text { isolated. }\end{array}$ \\
\hline $\begin{array}{l}\text { Students' } \\
\text { reaction to } \\
\text { course content }\end{array}$ & $\begin{array}{l}\text { Initially positive: } \\
\text { to lack of novelty } \\
\text { and variation in } \\
\text { content and } \\
\text { learning strategies }\end{array}$ & $\begin{array}{l}\text { Moderate: too little } \\
\text { interactivity and some } \\
\text { outdated materials }\end{array}$ & $\begin{array}{l}\text { Poor: volume of work, } \\
\text { lack of support and lack } \\
\text { of opportunity to see } \\
\text { growth negatively } \\
\text { influence confidence }\end{array}$ & $\begin{array}{l}\text { Reasonable: } \\
\text { throughout the } \\
\text { course }\end{array}$ \\
\hline
\end{tabular}




\begin{tabular}{|l|l|l|l|l|}
\hline $\begin{array}{l}\text { Characteristics } \\
\text { of support } \\
\text { during the } \\
\text { course }\end{array}$ & $\begin{array}{l}\text { Minimal: only } \\
\text { contact is through } \\
\text { feedback on } \\
\text { assignments }\end{array}$ & $\begin{array}{l}\text { Reasonable: although } \\
\text { feedback seldom shows } \\
\text { connections to students' } \\
\text { daily circumstances }\end{array}$ & $\begin{array}{l}\text { Poor: Feedback is } \\
\text { positive, but not aimed } \\
\text { at affective needs }\end{array}$ & Reasonable to low. \\
\hline Summary & $\begin{array}{l}\text { Reasonable to } \\
\text { poor: initial } \\
\text { attention soon } \\
\text { slipping }\end{array}$ & $\begin{array}{l}\text { Relevance continues, } \\
\text { although it diminishes }\end{array}$ & $\begin{array}{l}\text { Confidence: low unless } \\
\text { very good academic } \\
\text { results }\end{array}$ & $\begin{array}{l}\text { Reasonable: would } \\
\text { become a problem if } \\
\text { other issues were } \\
\text { resolved. }\end{array}$ \\
\hline $\begin{array}{l}\text { Examples of } \\
\text { motivational } \\
\text { strategies }\end{array}$ & $\begin{array}{l}\text { Bring pacing into } \\
\text { the course; reward } \\
\text { early completion; } \\
\text { offer assistance }\end{array}$ & $\begin{array}{l}\text { Provide occasional } \\
\text { extra material; give } \\
\text { creative feedback linked } \\
\text { to learners'work and } \\
\text { daily circumstances }\end{array}$ & $\begin{array}{l}\text { Reassure learners; show } \\
\text { empathy and } \\
\text { encouragement; } \\
\text { emphasize their being } \\
\text { part of a group }\end{array}$ & $\begin{array}{l}\text { Ensure instructors } \\
\text { are accessible; refer } \\
\text { to positive feelings } \\
\text { when successful; } \\
\text { reward early } \\
\text { completion }\end{array}$ \\
\hline
\end{tabular}

The motivational interventions were applied in Courses B, C, D and E (Course A did not make use of any motivation messages). College instructors for these groups were trained by the researcher for their role in the research and also were provided an instructor guide specifically designed to accompany the research. In Courses B and D, eight motivational messages were designed by the instructors, based on an initial motivational audience analysis and the ARCS model of motivational analysis. In Courses $\mathrm{C}$ and $\mathrm{E}$, instructors designed their own messages based on an initial audience analysis and on the motivational needs of their students as they became apparent during the course, also based on the ARCS model. The instructors involved in the research worked on their own, without any contact or interference from the researcher. The involvement of the instructor in Course A (the group which did not use motivational messages) was limited to registering how much time was spent on giving assignment feedback on the assignments. Other instructors used their logbooks to note student remarks and to record their own observations and other important data. These instructors also used time sheets to record the extra time spent on the motivational activities as compared with the time that normally would have been spent on feedback had the motivational intervention had not been introduced.

The initial student questionnaire had shown that the greatest expected problems were in the area of confidence. Forty-one of 63 students mentioned that they expected problems in this area. (It should be noted that students of Course A did not get the audience analysis questionnaire as no motivational messages were distributed.) The collective 
messages had been prepared and made ready for mailing by the instructors of courses B and $\mathrm{D}$ before the courses started, and at eight times during the course, at agreed dates, the instructor sent off the se messages. A computer program was used to make the drawings on the messages.

\section{Outcomes}

At the end of the course year, instructors turned in their logbooks, time monitoring sheets, copies of the motivational messages and the various communications they had had with the students. They also reported the completion rate of their respective courses. The completion rates as reported are depicted in Table 7.

Table 7 Student completion rates in the main study

$\begin{array}{cccc}\text { Course } & \text { Number of students } & \text { Number of completers } & \text { Motivational activities } \\ \text { A } & 18 & 7 & \text { None } \\ \text { B } & 13 & 7 & \text { Collective } \\ \text { C } & 14 & 11 & \text { Personalized } \\ \text { D } & 18 & 11 & \text { Collective } \\ \text { E } & 18 & 7 & \text { Personalized }\end{array}$

Upon reviewing the information supplied by the instructors, it was discovered that the instructor for Course $\mathrm{E}$ had only distributed three motivational communications, all of which had all been sent out the first three months of the course. The other five months of Course E contained no structured contact between the instructor and the students. (Because the researcher had no contact with this instructor during the study's implementation, this deficiency was not discovered until data collection and analysis was completed.) As a result, the data associated with Course E was not included in the study's final results. The instructor stated that the reason for not implementing the research procedure was that he had been involved in international work, and thus had not had the expected amount of time available to participate in this study. 
The motivational messages were found to be effective in increasing the proportion of students completing the courses as compared to previous years. Of the 81 students enrolled in all the Foundation courses, 42 successfully completed the courses (52\%). The two preceding years, this number had been reported as 18 of the 49 students (27\%) and 29 of the 67 students $(43 \%)$ respectively. Looking at those courses where motivational messages had been administered, we find that 29 of the 45 enrolled students successfully finished the course (64\%). In spite of the somewhat low value for $N$, we find that 11 of the 14 students who received personalized messages successfully finished the course (79\%), and 18 of the 31 students who received collective messages successfully finished the course $(59 \%)$.

Implementing the collective motivational messages was not as time consuming in the main study as it had been in the pilot study. Instructor time sheets revealed that the total time did not surpass the eight hours per student (the number of hours that had been set aside by the college for instruction and grading). The rather high instructional time for the collective messages, shown in Table 8 , may have been influenced by the fact that one of the instructors was new to the program.

Table 8 Overview of average grading and motivational support time

$\begin{array}{lccc}\text { Type of support } & \begin{array}{l}\text { Instruction/grading time } \\ \text { (in minutes) }\end{array} & \begin{array}{l}\text { Motivational support } \\ \text { time ( in minutes) }\end{array} & \text { Total } \\ \text { None (Course A) } & 322 & \text { None } & 322(5 \mathrm{~h} .22 \mathrm{~min}) \\ \text { Collective } & 334 & 144 & 478(7 \mathrm{~h} .58 \mathrm{~min}) \\ (\text { Course B, D) } & 292 & 184 & 476(7 \mathrm{~h} .56 \mathrm{~min}) \\ \text { Personalized } & & & \end{array}$

Forty-five questionnaires were sent out to discover the effect of the motivational messages on students. No questionnaires were sent to Course A students (as no 
motivational intervention had been planned) and Course $\mathrm{E}$ (as the intervention did not take place as planned). Twenty-five students returned the questionnaires. It was found that, in general, students liked the motivational messages. An overview of the effects of the motivational messages on the students is provided in Table 9.

Table 9 Effect of the motivational messages in Courses B, C and D

$\begin{array}{llllll}\text { Summary of question } & \begin{array}{l}\text { Agree } \\ \text { completely }\end{array} & \text { Agree partly } & \begin{array}{l}\text { Disagree } \\ \text { partly }\end{array} & \begin{array}{l}\text { Disagree } \\ \text { completely }\end{array} & \begin{array}{l}\text { ARCS } \\ \text { component }\end{array} \\ \begin{array}{l}\text { The first [pacing] letter was } \\ \text { useful }\end{array} & 13 & 7 & 2 & 1 & \begin{array}{l}\text { Attention } \\ \text { Confidence }\end{array} \\ \begin{array}{l}\text { Notes encouraged to continue } \\ \text { with course }\end{array} & 14 & 8 & 2 & 1 & \text { Confidence } \\ \begin{array}{l}\text { Presentation of notes was } \\ \text { stimulating }\end{array} & 10 & 11 & 2 & - & \text { Confidence } \\ \begin{array}{l}\text { I was looking forward to } \\ \text { receiving the notes }\end{array} & 7 & 11 & 4 & 1 & \begin{array}{l}\text { Attention } \\ \text { Relevance } \\ \text { Notes contributed to pleasure in } \\ \text { course }\end{array} \\ \begin{array}{l}\text { Notes made finishing the course } \\ \text { easier }\end{array} & 12 & 11 & - & 1 & \text { Satisfaction } \\ \text { N=25 } & 6 & 8 & 9 & 2 & \text { Satisfaction } \\ & & & & & \end{array}$

After a careful review of the returned questionnaires, the last question became suspected as being inadequately formulated. Some students explained that the course had not become easier (course content), but that doing the course had become easier. However, since the motivational messages were designed to help at an affective, but not academic, level, it seemed apparent that students had likely misinterpreted the intent of the question. The students frequently made observations on their questionnaires related to the affective content of the messages such as, "The notes encouraged me to have a high degree of motivation to continue", "The notes have built my confidence and motivation", "There were times that I felt I couldn't go on...but these notes encouraged me to go on", "The tutor [the term "tutor" in the UK tradition is the equivalent of "instructor" in the US tradition of distance education] cared", "They [the notes] encouraged me to open a dialogue which I find difficult", "It helped me to get going", "Notes were important to my confidence”, “... built my confidence and strengthened my motivation”, "Encouraged 
and pointed out success", and so on. Three students who had received collective messages made slightly less positive comments: "I have met my tutor personally, I think it makes a big difference. It is better than fax, email or little notes. I don't think adults need a lot of notes;" "The truth is I don't remember the notes, although they are all in my file;" "Whilst I appreciated the notes, they were not based on individual need." Many students in their communications also referred to how the messages had helped them to stay in touch with their instructor and how they could bring up questions related to course content and study methods.

\section{An example of a dialogue}

To provide a deeper view of how the communication between instructor and learner developed in some cases, we present for examination here the specific case of David. A brief profile of David follows.

David holds two BA's (Divinity and Education). According to the information given in the initial questionnaire, David enrolled in the program because he is being required to develop correspondence courses and would like to gain an improved understand ing of the course development process. David has expressed concern that he is worried because of the time constraints imposed by his the responsibility for "the supervision of a church". (David has only five hours per week to study, half the minimum required time). Replying to what kind of help he thought the instructor could best give him, he suggests that he wants to know the strengths and weaknesses of the assignments he submits. He does not want to receive the names of other students in the course, nor does he wish his name to be given to fellow students. David is an American, but he works in an Asian country. (This country has an excellent open university, offering dozens of programs and hundreds of courses.) It was important to him that his wish to study on his own, without getting in touch with other students, be respected.

Although David apparently was reluctant to engage in communication with his fellow learners and the instructor, he gradually gave up his reserved attitude. After having been 
in the course for three months with no contact with the instructor and no submitted assignments, David finally sent the instructor a letter of thanks for the motivating notes. He apologized for the delayed response and presented a schedule for sending in the required assignments. He signed his letter with his full name and clerical titles. Two months before the end of the course, he reacted again by stating: "Thanks for the note and encouragement which I received this morning... desperation struck last night". He signs with his first name. Just before the exam he sends the instructor a photograph of himself, wife and children. Answering the final questionnaire, he mentions that he liked Note 3, which stressed the importance of communication between the instructor and the student. The note "encouraged me to open up a personal dialogue which I find difficult". He also mentions that the notes helped "to reduce stress and lack of confidence". He also said he liked the second message, which forced him "to prioritize and set deadlines". He states that he feels the purpose of the notes has been to develop a dialogue and to communicate support. He ends his letter with thanks for the extra effort and time the instructor has made available to accompany him. Given David's reluctance to engage in communication, the notes may have been an acceptable and encouraging way to get support without having to engage in an open dialogue. His last remark reads: "The college was one of the many demands on my desk, but the tutor was a friend".

\section{Conclusions}

The research discussed in this paper was designed to contribute to solving the pervasive problem of high dropout rates in distance education. A developmental research approach was used in the study, where a protypical motivational message was continuously evaluated and improved, leading to a final version of the motivational message which consisted of a combination of text and graphics delivered by standard postal mail.

The study also attempted to develop an improved understanding of the social and motivational processes found in the distance learning setting. This study argues that it is important to gain further insight into the applied processes of such motivational strategies if such processes are to be improved. Further, the considerable variance in student 
support in real life contexts makes it essential that we understand how to apply specific and appropriate strategies for the context in which we are working if learner motivation is to increase.

A single, detailed case of a student functioning in the affectively enhanced distance learning environment (the case of David) was presented. Other similar accounts were likewise gathered and recorded. These case studies provided rich descriptions of the impact of motivational strategies in the distance learning setting, and more specifically, gave evidence that the implementation of motivational messages not only positively influenced learning in a restricted sense, but also improved learners' communicative at a meta-cognitive level (via the discussion of problems related to study strategies and methods for handling course work and examinations).

Based on the outcomes of the main study it was found that:

- Motivational strategies improved the disposition of the learners to finish the course successfully.

- The number of learners successfully finishing the courses increased.

- Collective me ssages were more cost efficient than personalized messages.

- There was no conclusive evidence that the use of personalized messages was more effective than the use of collective messages

- The messages had a particularly strong impact on an improved level of selfconfidence of the learners.

- The use of motivational strategies resulted in an enrichment of the student support system.

\section{Closing remarks}

This research study has provided strong evidence that motivational communications in distance education can be effective in improving both the motivational level of individual students and the overall retention rates of groups of students taking distance learning 
courses. These findings were found to be true even in a situation where the existing student support system was technologically unsophisticated (i.e., traditional postal services). Unfortunately, even in cases where distance education institutions support their students using technologically more advanced media such as telephone, fax, e-mail, and Internet chats, much of the support typically focuses almost exclusively on the cognitive needs of the students, rather than their affective needs (Zvacek, 1991). As the learning landscape is gradually changing and more and more learning opportunities are being offered through means of distance education, it will be important that increased attention be given to the motivational dimension of (and between) distance learners. Finally, the study recommends that distance education systems should consider the affective needs of their students as an integral and essential component of the educational process, along with the more traditional components such as course materials, course delivery, evaluation of learning outcomes and the provision of cognitive and administrative support.

\section{References}

Akker, J.J.H. van den, \& Plomp, Tj. (1993). Development research in curriculum: Propositions and experiences. Paper presented at the annual meeting of the American Educational Research Association, April 12-14, Atlanta, GA.

Bates, A.W. (2000). Managing technological change. San Francisco: Jossey Bass

Del Soldato, T., and du Boulay, B. (1995). Implementation of motivational tactics in tutoring systems. Journal of Artificial Intelligence in Education, 6(4), 337-338

Graham S. \& Weiner, B. (1996). Theories and principles of motivation. In D.C. Berliner \& R.C. Calfee (Eds.), Handbook of educational psychology (pp. 63-84). New York, NY: Macmillan

Keller, J.M. (1983). Motivational design of Instruction. In C.M. Reigeluth (Ed.), Instructional 
Design theories and models: An overview of their current status. Hillsdale, NJ: Lawrence Erlbaum Associates

Keller, J.M. (1987). Strategies for stimulating the motivation to learn. Performance \& Instruction Journal 26(8), 1-8

Keller, J.M. (1999). Motivation in cyber-learning environments. International Journal of Educational Technology, 1(1) 7-30.

Keller, J.M. (1999). Motivational Systems. In H. Stolovitch, \& E. Keeps (Eds.), Handbook of human performance technology $\left(2^{\text {nd }}\right.$. ed., $)$. San Francisco: Jossey Bass Inc. Publishers

Keller, J.M. \& Litchfield, B.C. (2002). Motivation and Performance. In A.A. Reiser and John V. Dempsey (Eds.). Trends and Issues in Instructional Design and Technology. N.J.: Merril Prentice Hall.

Kemp. J.E., Morrison, G.R. \& Ross S.M. (1999). Designing effective instruction. New York: John Wiley

Maslow, A.H. (1954). Motivation and personality. New York: Harper

Moore, M.G. \& Kearsley, G. (1996). Distance Education - A systems view. Belmont. CA: Wadsworth Publishing Company.

Richey, R.T., \& Nelson, W.A. (1996). Development research. In D. Jonassen (Ed.), Educational communications and technology. London: Macmillan

Rogers, C.R. (1969). Freedom to learn. Columbus, Ohio: Merrill

Smith, P.L. \& Ragan, T.J. (1999). Instructional Design. New York: Wiley \& Sons

Song, S.H. \& Keller, J.M. (2001). Effectiveness of motivationally adaptive computer-assisted instructions on the dynamic aspects of motivation. Educational Technology Research and Development, 49(2), 5-22 
Suzuki, K. \& Keller, J.M. (1996). Creation and cross cultural validation of an ARCS motivational design matrix. Paper presented at the annual meeting of the Japanese Association for Educational Technology, Kanazawa, Japan.

Visser, J. (1989) Enhancing learner motivation in an instructor-facilitated learning context. Tallahassee, FL: Florida State University (unpublished dissertation)

Wlodkowsky, R.J. (1985). Enhancing adult motivation to learn: A guide to improving instruction and increasing learner achievement. San Francisco: CA: Jossey Bass.

Wolcott, L.L. \& Burnham, B.R. (1991). Tapping into motivation: What adult learners find Motivating about distance instruction. Proceedings of the $7^{\text {th }}$ annual conference on Distance Teaching and Learning (pp. 202-207). Madison, WI.

Yin, R.K. (1994). Case study research: Design and methods. Beverly Hills, CA: Sage

Zvacek, S.M. (1991). Effective affective design for distance education. TechTrends 36(1), 40-43.

\section{Author information}

Lya Visser [lvisser@ learndev.org] is Program Professor and Director of Applied Research in the Instructional Technology and Distance Education programs at Nova Southeastern University's School of Education and a training developer with the Learning Development Institute.

Tjeerd Plomp [tjeerd_plomp@cs.com] is Professor of Education at the University of Twente, where he served as Dean and chaired the Department of Curriculum.

Ray J. Amirault [ramirault@learndev.org] is a researcher at the Learning Development Institute and a doctoral candidate at Florida State University's Department of Educational Research. 
Wilmad Kuiper [w.a.j.m.kuiper@edte.utwente.nl] is Associate Professor at the University of Twente.

\section{Acknowledgement}

The authors wish to thank Donald P. Ely, Professor Emeritus and Associate Director of the ERIC Clearinghouse on Information \& Technology, Syracuse University, for his contribution to advising on and editing the pre-final draft. 